DOE/ID/13219

Energy Efficient Aluminum Production - Pilot-Scale Cell Tests

Final Report for Phase I and Phase II

03/01/1994 - 11/30/1998

R. A. Christini

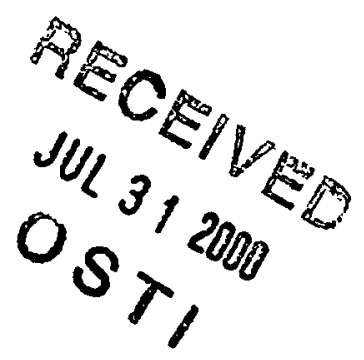

December 1999

Work Performed Under Contract No. DE-FC07-94ID13219

For

U.S. Department of Energy

Assistant Secretary for

Energy Efficiency and Renewable Energy

Washington, DC

By

Alcoa Incorporated

Alcoa Center, PA 


\section{DISCLAIMER}

This report was prepared as an account of work sponsored by an agency of the United States Government. Neither the United States Government nor any agency thereof, nor any of their employees, make any warranty, express or implied, or assumes any legal liability or responsibility for the accuracy, completeness, or usefulness of any information, apparatus, product, or process disclosed, or represents that its use would not infringe privately owned rights. Reference herein to any specific commercial product, process, or service by trade name, trademark, manufacturer, or otherwise does not necessarily constitute or imply its endorsement, recommendation, or favoring by the United States Government or any agency thereof. The views and opinions of authors expressed herein do not necessarily state or reflect those of the United States Government or any agency thereof. 


\section{DISCLAIMER}

Portions of this document may be illegible in electronic image products. Images are produced from the best available original document. 


\title{
ENERGY EFFICIENT ALUMINUM PRODUCTION - PILOT-SCALE CELL TESTS FINAL REPORT FOR PHASE I AND PHASE II 03/01/1994-11/30/1998
}

\author{
R. A. Christini
}

December 1999

Work Performed Under Contract No. DE-FC07-94ID13219

\author{
Prepared for the \\ U.S. Department of Energy \\ Assistant Secretary for \\ Energy Efficiency and Renewable Energy \\ Washington, DC
}

\author{
Prepared by \\ Alcoa Incorporated \\ Alcoa Center, PA
}




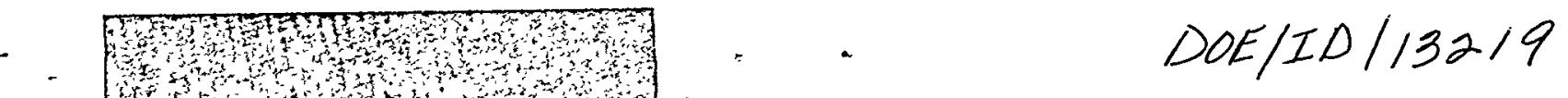

1999 December 30

Cooperative Agreement

No. DE-FC07-94ID13219

\section{ALCOA TECHNICAL CENTER 100 TECHNICAL DRIVE • ALCOA CENTER, PA 15069-0001}

\section{Energy Efficient Aluminum Production - Pilot-Scale Cell Tests}

\section{Final Report for Phase I and Phase II}

Submitted to:

U. S. Department of Energy

Idaho Operations Office

850 Energy Drive

Idaho Falls, Idaho 83401-1563

Creating Value through Technology 


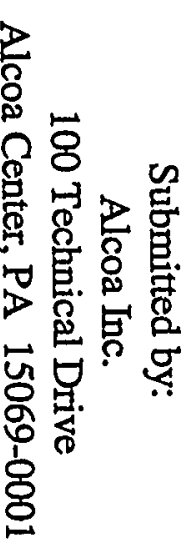

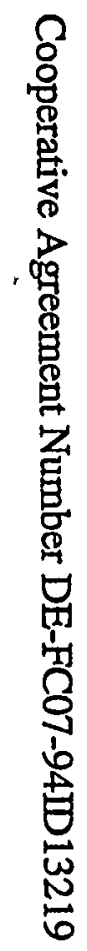

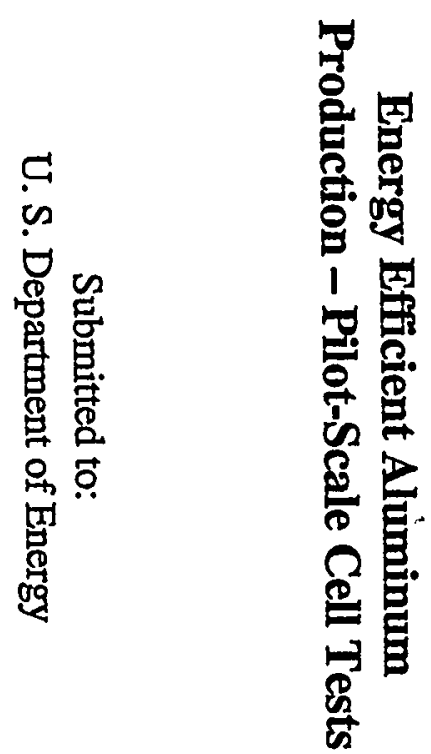


This report was prepared as an account of work sponsored by an agency of the United States Government. Neither the United States Government nor any agency thereof, nor any of their employees, makes any warranty, express or implied, or assumes any legal liability or responsibility for the accuracy, completeness, or usefulness of any information, apparatus, product, or process disclosed, or represents that its use would not infringe privately owned rights. Reference herein to any specific commercial product, process, or service by trade name, trademark, manufacturer, or otherwise, does not necessarily constitute or imply its endorsement, recommendation, or favoring by the United States Government or any agency thereof. The views and opinions of authors expressed herein do not necessarily state or reflect those of the United States Government or any agency thereof.

This report has been reproduced from the best available copy. Available in paper copy and microfiche.

Number of pages in this report: 27

DOE and DOE contractors can obtain copies of this report from: Office of Scientific and Technical Information, P. O. Box 62, Oak Ridge, TN 37831. (615) 576-8401.

This report is publicly available from the Department of Commerce, National Technical Information Service, 5285 Port Royal Road, Springfield, VA 22161. (703) 487-4650. 


\section{TABLE OF CONTENTS}

ABSTRACT

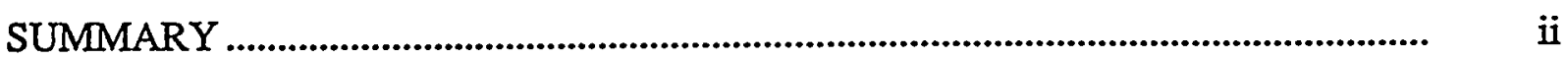

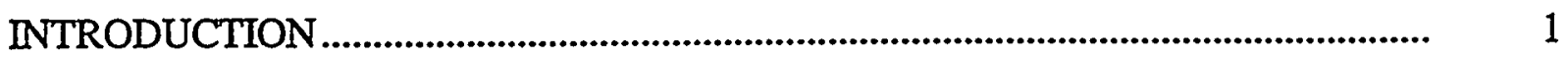

PHASE I OBJECTIVES.........................................................................................

PHASE I RESULTS................................................................................................

Conceptual Design .............................................................................................. 3

Technical Feasibility and Performance Calculations ..................................................

Current Density ............................................................................................ 7

Current Efficiency ............................................................................................... 7

Electrolyte Circulation.............................................................................................. 8

Thermal Design and Control ..................................................................... 9

Cell Performance and Economics ............................................................................ 9

Cermet Anode Materials and Fabrication...................................................................... 10

Cermet Anode Properties and Anode Assembly Design and Anode Corrosion Tests............................................................................ 10

Pilot Cell Design and Facility - Test Heaters and Electrolyte Containment........................................................................................ 11

Phase I Conclusions and Go/No-Go Decision............................................................. 11

PHASE II OBJECTIVES ......................................................................................... 12

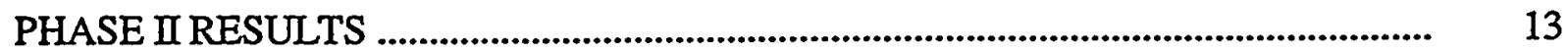

Pilot Cell Facility - Final Design and Construction..................................................... 13

Bench Scale Simulation.......................................................................................... 13

Final Cell Design Features ......................................................................... 13

Phase II Anode Fabrication Method ..........................................................................

Anode-To-Collector Bar Connection Method..................................................... 14

Fabrication of Pilot Anodes and Anode-to-Collector Bar Connections..................... 15

First Pilot Cell Operations......................................................................................... 15

First Cell Autopsy ................................................................................................... 17

Bench Cell Tests Following First Cell Autopsy................................................... 17

Design and Construction of Optimized Cell ............................................................ 17

The Optimized Cell Test .............................................................................................. 18

Current Efficiency Experiments ............................................................................ 19

Autopsy Optimized Cell....................................................................................... 19

Phase II Assessment .............................................................................................. 20 
A cermet anode that produces oxygen and a cathode material that is wetted by aluminum can provide a dimensionally stable inter-electrode distance in the Hall-Héroult cell. This can be used to greatly improve the energy and/or productivity efficiencies. The concept, which was developed and tested, uses a system of vertically interleaved anodes and cathodes. The major advantage of this concept is the significant increase in electrochemical surface area compared to a horizontal orientation of anode and cathode that is presently used in the Hall-Héroult process. This creates an additional advantage for energy reduction of $1.3 \mathrm{kWh} / \mathrm{lb}$ or a $20 \%$ productivity improvement.

The voltages obtained in an optimized cell test met the energy objectives of the project for at least two weeks. An acceptable current efficiency was never proven, however, during either pilot scale or bench scale tests with the vertical plate configuration. This must be done before a vertical cell can be considered viable. Anode corrosion rate must be reduced by at least a factor of three in order to produce commercial purity aluminum. It is recommended that extensive theoretical and bench scale investigations be done to improve anode materials and to demonstrate acceptable current efficiencies in a vertical plate cell before pilot scale work is continued. 


\section{SUMMARY}

There are two material technology components of this cooperative agreement, a cermet anode that produces oxygen and a cathode material that is wetted by aluminum. Together they can provide a dimensionally stable inter-electrode distance that can be used to greatly improve the energy and/or productivity efficiencies of the Hall-Heroult cell.

The key motives for commercialization are:

1. $20 \%$ reduction in the electrical energy used for aluminum smelcing $(1.3 \mathrm{kWh} / \mathrm{hb})$ or an increase in cell capacity of $20 \%$;

2. elimination of the energy and environmental consequences of the manufacture and use of carbon anodes for aluminum smelting (anode baking and cell room operations); and

3. technology that moves U.S. smelting capacity to the lower thind of the worldwide cost curve, requiring a 3-5 q//b reduction in cash cost.

Tho Cooperative Agreement is divided into two phases. The main focus of Phase I was to develop the cell concept to be pursued and Phase II was to test key elements of the cell concept.

The concept, which was selected, uses a system of vertically interleaved anodes and cathodes. The major advantage of this concept is the significant increase in electrochemical surface area compared to a horizontal orientarion of anode and cathode that is presently used in the Hall-Heroult process. In the same plan area the vertically arranged anode-cathode assembly increases the electrochemical surface area 3-4 times. This creates an additional advantage for energy reduction or productivity improvement.

Thermal analyses were used to establish the lining dosign and operating characteristics of the proposed cell. The predicted cell amperage and voltage are $131 \mathrm{kA}$ and 3.80 volts which gives an energy savings of $1.3 \mathrm{kWh} / \mathrm{hb}$. The heat loss required is about $1 / 3$ of the heat loss for a convencional aluminum-smelting cell operating at this amperage. This design will be much more sensitive to changes that influence the thermal balance of the cell than a conventional cell.

The anode material selected for Phase II testing was the $17 \%$ Cu cermet composition because of the large amount of data available on this material relative to new candidates.

For several hours of the first pilot cell test, the energy objectives of the project were achieved after one of two modules was cleared of a short circuit. The voltages obtained in the optimized cell test met the energy objectives of the project for at least two weeks.

Data was obtained on the effect of anode movement on cell voltage; and the ability to control a very low, heat loss cell with inert anode movement appears to be feasible.

An acceptable current efficiency was never proven during the pilot scale or bench scale tests with the vertical plate configuration. This must be done before a vertical cell 
concept can be considered viable. Anode corrosion rate must be reduced by at least a factor of three in order to produce commercial purity aluminum. It is recommended that extensive theoretical and bench scale investigations be done to improve anode materials and to demonstrate acceptable current efficiency results in a vertical concept cell before pilot scale work is continued. 


\section{INTRODUCTION}

The overall objectives of Alcoa -DOE Cooperative Agreement \#DE-PS07-931D13219 are:

- demonstration of cermet anode stability in a cell concept that can be used for the energy efficient production of aluminum,

- exploitation of favorable cell operating conditions from previously funded DOE research on cermet anodes, stable aluminum wetted cathodes and electrolyte flow, and

- to encourage the commercialization of developed technology for energy officient production of aluminum.

The key motives for commercialization are:

- $20 \%$ reduction in the electrical energy used for aluminum smolting ( $1.3 \mathrm{kWb} / \mathrm{lb})$ or an increase in cell capacity of 20\%;

- elimination of the energy and environmental consequences of the manufacture and use of carbon anodes for aluminum smelting (anode baking and cell room operations); and

- technology that moves U.S. smelting capacity to the lower third of the worldwide cost curve, requiring a 3-5 $₫ / \mathrm{lb}$ reduction in cash cost.

The exploitation of the two material technology components of this cooperative agreement, a cermet anode that produces oxygen and a cathode material that is wetted by aluminum, provides a dimensionally stable inter-electrode distance that can be used to greatly improve the energy and/or productivity efficiencies of the Hall-Héroult cell.

Figure 1 shows a cross-section of a Hall-Heroult cell viewed from the end. The passage of current in the short 1-1/2" to 2" space between the carbon anode and the molten aluminum cathode is a major source of energy consumption in the process. Therefore, the reduction of the anode-cathode distance (ACD) and/or a reduction of the current density in the ACD will improve the power efficiency of the process. However, a reduction in current density must be achieved without loss of cell productivity for economic benefit. The potential energy savings for an average U.S. industry aluminum-smelting cell is estimated to be approximately $1.3 \mathrm{kWh} / \mathrm{lb}$ of aluminum produced. This $20 \%$ saving at the cell represents a $35 \%$ reduction in the energy consumption to produce aluminum starting from fossil fuel.

The Cooperative Agreement is divided into two phases. The main focus of Phase $I$ is to develop the cell concept to be pursued and Phase II is to test key elements of the cell concept. The main technical hurdles for these developments are:

- low cost, durable and corrosion resistant materials for the anode, cathode and cell lining; 


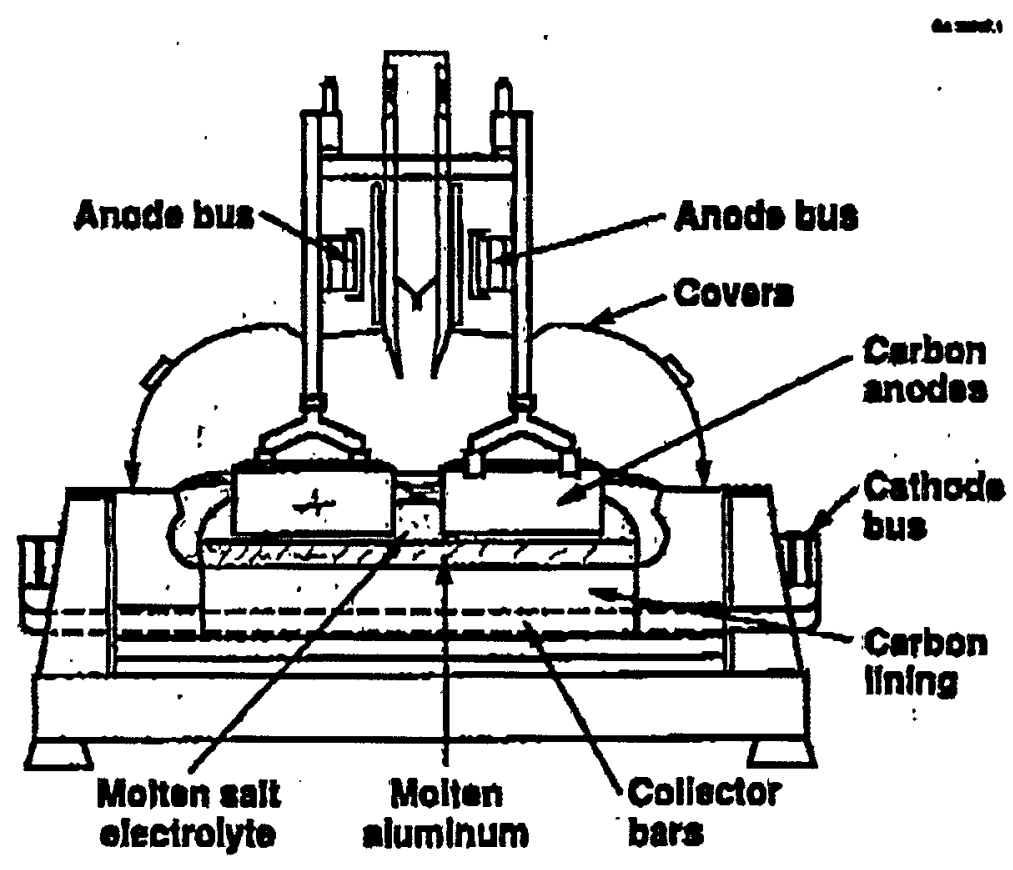

Ead view cross-section of a Hall-Héroult Cell

Figure 1

- alumina feed stock and cell design that will enable cell operation near alumina saturation concentration;

- achieving acceptable aluminum purity;

- cell power control at high energy efficiency;

- materials that withstand high temperature oxygen gas and olectrolyte fume;

- a highly insulating lining and lid design; and

- a retrofit cell design that meets cost and energy objectives.

\section{PHASE I OBJECTIVES}

A critical objective of this Phase I was to select the appropriate cell design concept to be used in a prototype demonstration. This Phase also brings to focus the engineering aspects of the design that must be adequately addressed for successful cell operation. In Pbase II the elements of the commercial design of the cell concept will be tested.

Phase I of Alcoa's research plan included:

- development of a concept for commercial cell design that meets energy / capacity goals;

- assessment of the commercial cell design technically and economically;

- development of anode materials and designs for the Phase II cell;

- fabrication of cermet anodes for performance and property measurements; and development of a Phase II cell design and facility and testing of heating and lining designs for the cell. 
The key milestones for Phase I include:

- engineering estimates that show that the cell concept to be used in Pbase II can achieve a $20 \%$ reduction in $\mathrm{kWh} / \mathrm{hb}$ or a $20 \%$ increase in cell capacity at a commercial scale;

- phase II pilot cell design that will demonstrate commercial viability of the cell concept;

- anode assembly design that does not exceed acceptable stress levels and has <10\% variation in current density; and

- testing that demonstrates a one-month life for the heating system and lining for the Phase II pilot cell.

\section{PEASE I RESULTS}

\section{Conceptual Design}

Since cell desigm is critical for the overall success of the Program, a specific task at the start of this Program was devoted to defining cell concepts and assessing their atuributes and feasibility. This was accomplished by a two day meeting that brought together key technologists from previous DOE programs, Alcoa personnel and consultants to examine the approaches and issues related to the cell concepts for the energy efficient production of aluminum. The technologists attending included:
W. E. Haupin
N. E. Richards
Dr. J. E. Evans
Dr. U Landau
M. M. McMonigle
J. V. Anderson
Dr. L. Joo
Dr. L: VanDillen
Dr. S. Marschman
Dr. C. Windisch
Dr. D. Belitskus
R. K. Bergstrom
J. N. Bruggeman
Dr. R. A.Christini
R. K. Dawless
N. M. Fizgerald
J. D. Green
A. F. LaCamera
Dr. S. Ray
R. C. Schoener
R. L. Troup
G.P. Tarcy
Dr. D. P. Ziegler

Consultant - Retired (Alcoa)

Consultant - Retired (Reynolds Metal Co.)

University of California - Berkeley

Case Western University

DOE - Washington

EG\&G Idaho, Inc.

Great Lakes Research Corporation

Ceramic Magnetics Inc.

Pacific Northwest Laboratory

Pacific Northwest Laboratory

Alcoa Technical Center

Alcoa Technical Center

Alcoa Technical Center

Alcoa Technical Center

Alcoa Technical Center

Alcoa Technical Center

Alcon Technical Center

Alcoa Technical Center

Alcoa Technical Center

Alcoa Technical Center

Alcoa Technical Center

Alcoa Technical Center

Alcoa Technical Center 
At the conclusion of this meeting four altemate designs were proposed, the pros and cons of the designs were debated, and key enablers were identified. The enablers were:

- controlling alumina near saturation concentration, feeding and dissolution;

- interelectrode gas handling to avoid foaming and the resultant electrical resistance and electrolyte circulation problems;

- cell design that minimizes anode corrosion;

- corrosion resistant, mechanically stable electrode connections;

- current distribution within specifications to avoid electrochemical decomposition of fluorides rather than oxides; and

- control of ledge and crust in cell.

One of the major goals of Phase I was to establish a cell concept that addresses the enablers highlighted in the cell design, that satisfies the goals of this project in energy officiency, productivity and cost reduction, and that uses an oxygen generating anode and wetted cathode that form $x$ dimensionally stable inter-electrode distance. The concept chosen is shown schematically in Figure 2. The concept uses a system of vertically interleaved anodes and cathodes. The major advantage of this concept is the significant increase in electrochemical surface area compared to a horizontal orientation of anode and cathode that is presently used in the Hall-Heroult process. In the same plan area the vertically arranged anode-cathode assembly increases the electrochemical surface area 3-4 times. This creates an additional advantage for energy reduction or productivity improvement. From the energy standpoint, the larger the area through which a fixed current flows the lower the voltage drop associated with the current flow. Increases in productivity are also possible without an increase in cell voltage using the vertically interleaved electrode design, but are dependent on anode electrical conductivity. The higher surface area and the dimensionally stable ACD constitute the cell design and materials developments being capitalized on to achieve the goals set forth.

Dimensionally stable electrodes, the cermet anode (oxygen generating) and the $\mathrm{TiB}_{2}$ cathode (aluminum wetted), enable the consideration of a vertically arranged concept. An engineering drawing of an electrode module designed in Pbase I is shown in Figure 3. 


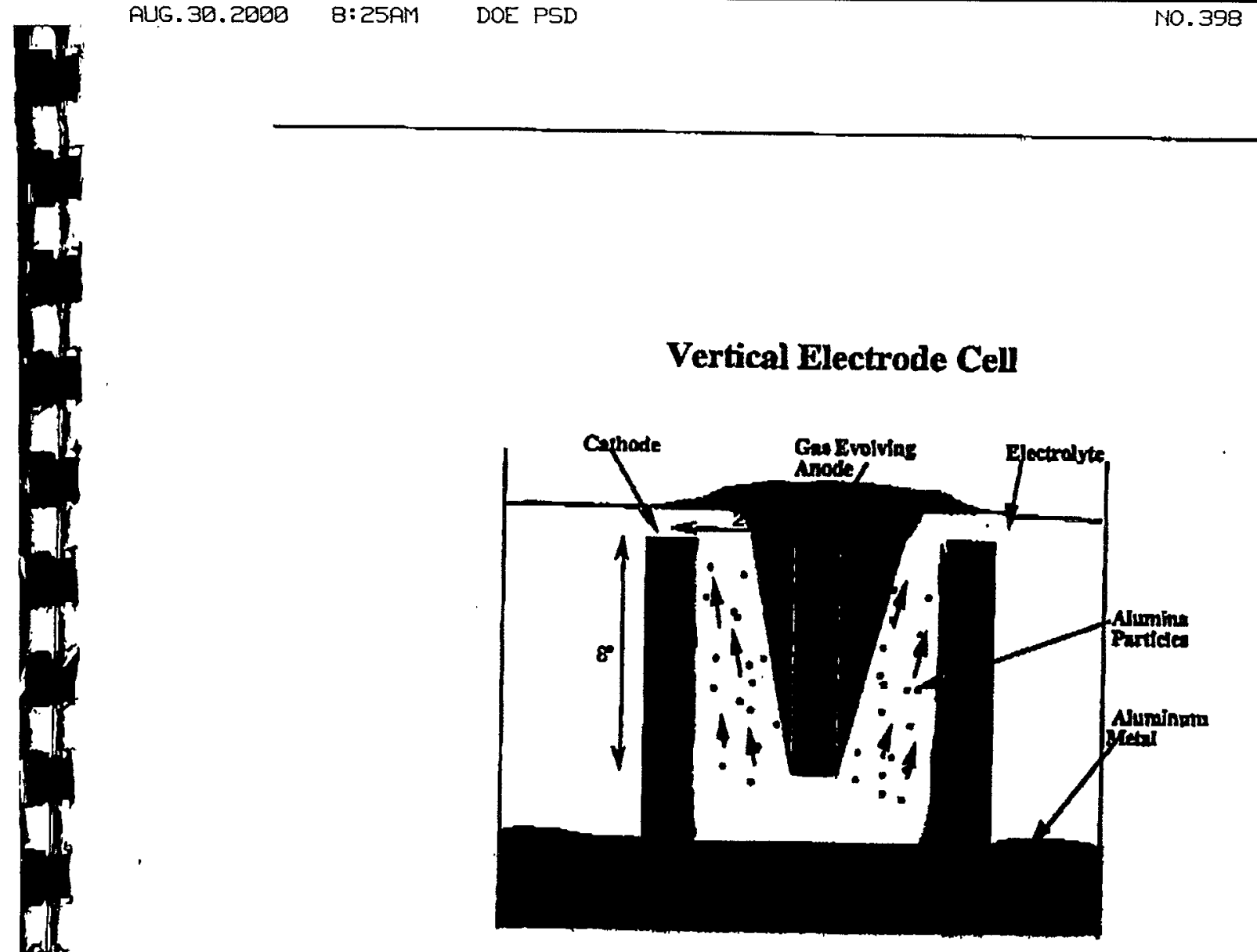

Figure 2. Schematic of Vertical Electrode Cell 


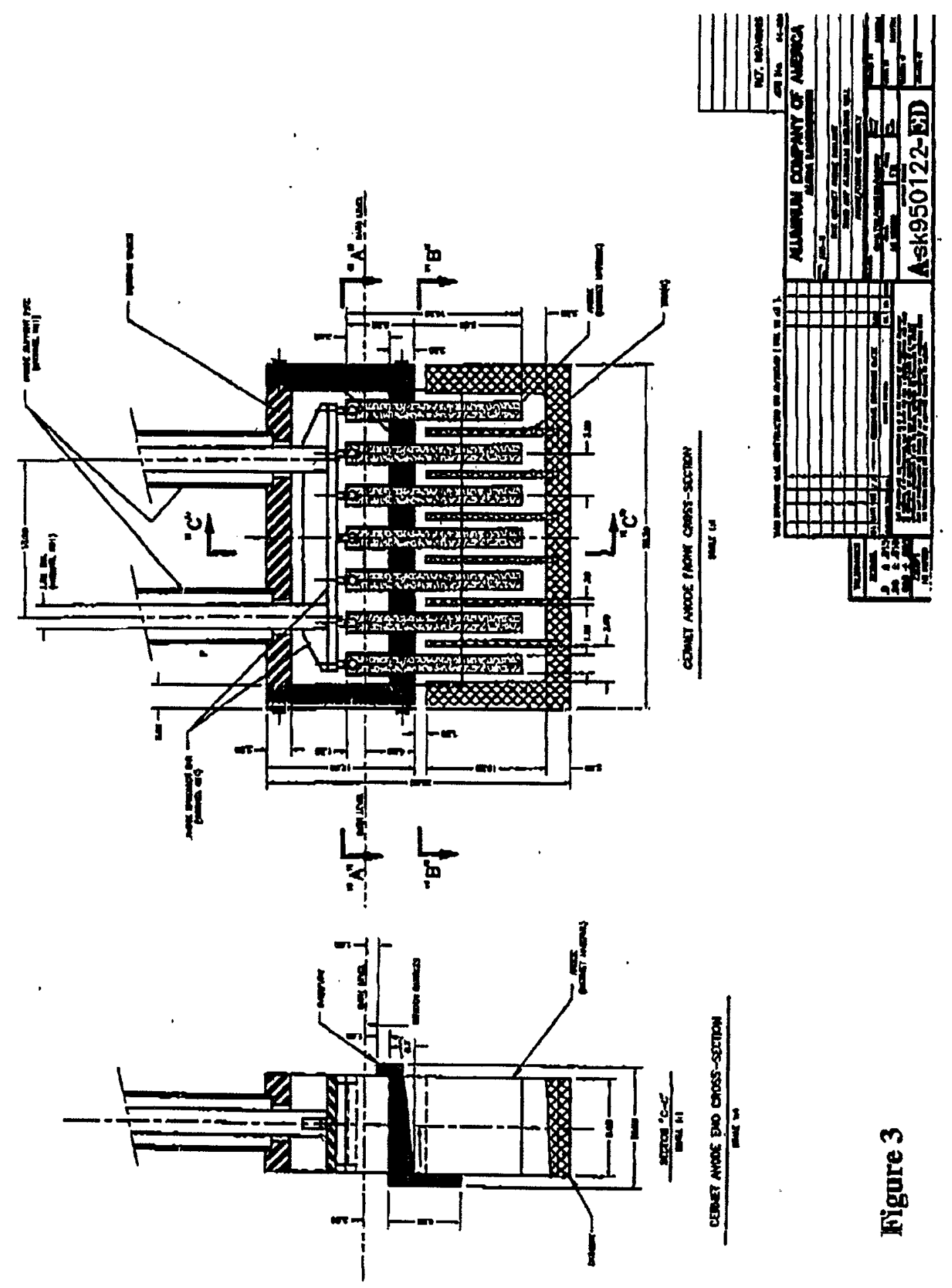




\section{Technical Feasibility and Performance Calculations}

The engineering analysis conducted in Phase I has shown that this electrode module can achieve the energy, production and cost saving goals for the project. The design also has the potential to improve anode performance and provides the electrolyto circulation to operate near alumina saturation - a key requirement for achieving Jow anode wear. The cell is designed to operate at a 1" ACD at current density between 0.25 to $0.50 \mathrm{~A} / \mathrm{cm}^{2}$. The ACD and current density are approximately $50 \%$ of present cell conditions and sustain or increase cell productivity. The predicted cell voltage for the design in Figure 3 is 3.8 volts which gives an energy savings of $1.3 \mathrm{kWh} / \mathrm{hb}$.

The cell voltage predicted has a high probability of being achieved because the basic phenomena driving the reduction in voltage aro well understood. These are that the reduction in ACD and reduction in current density. These directly impact the ohmic voltage drop in the cell as shown in Equation 1.

$$
\Delta \mathbf{V}=\mathbf{p} \cdot \mathbf{i} \cdot \mathbf{L}
$$

Rho is the resistivity of the electrolyte, $i$ is the current density and $L$ is the $A C D$. To reduce voltage drop caused by metal pad waves in a conventional Hall cell requires magnetic stabilization of the cell. The voltage reduction associated with this technology requires material stability. Given matorial stability, the voltage reduction can be achioved.

\section{Current Density}

The two Phase I goals related to curreat density were to limit current density to a maximum of $1.00 \mathrm{~A} / \mathrm{cm}^{2}$ and to limit current density distribution variation to less than $10 \%$. These design criteria are driven by the goal of minimizing anode wear and reducing cell operating sensitivity associated with maintaining near alumina saturation conditions. Using a 2-D current distribution model of the vertical electrode arrangement, it was shown that using an 8 " long 1"-1.5" thick 17\% Cu cermet anode resulted in a maximum current density of $0.45 \mathrm{~A} / \mathrm{cm}^{2}$. This was validated using a 3-D simulation of the electrode geometry. Since the vertical electrode provided a significant increase in surface area, lowering the current: density well below $1.00 \mathrm{Acm}^{2}$, the design criteria to achieve $<10 \%$ variation in current density was rolaxed. The predicted current density is between $0.51 \mathrm{~A} / \mathrm{cm}^{2}$ near the top of the anode and $0.18 \mathrm{~A} / \mathrm{cm}^{2}$ near the bottom based on the 3-D analysis.

\section{Current Efficiency}

A number of cell design factors influence cell current efficiency and current efficiency impacts cell productivity and energy efficiency. The typical current efficiency range for the Hall-Héroult cell is 90-94\%. The cell design factors that can influence current efficiency are electrolyte flow, current density and the tendency for the cell to short. Shorting was not expected to be a problem for this cell design because it uses a drained wetted catbode and relatively large $A C D$. The influences of electrolyte flow and current density on current efficiency are critical and are coupled phenomena. The back reaction that causes current 
efficiency loss is aluminum reacting with oxygen in solution or in the gas phase to produce alumina.

$$
\mathrm{Al}+3 / 4 \mathrm{O}_{2} \rightarrow 1 / 2 \mathrm{Al}_{2} \mathrm{O}_{3}
$$

Two models of the electrolyte flow in the ACD were used to assess the impact of cell design on current efficiency. The main limitation in this analysis was the uncertainty in the turbulence model being used to estimate the back reaction rate. Therefore a reliable prediction of current efficiency was not possible. However, based on the models, important design directions for the cell emerged. The main conclusions from this assessment are:

- loss of current efficiency is controlled by the rate of dissolution of metal from the wetted cathode surface; and

- the dissolution of oxygen from the anode or gas in the ACD will not be a controlling factor. $\left(\mathrm{O}_{2}\right.$ solubility in the electrolyte is estimated to be 300 times smaller than $\mathrm{CO}_{2}$.)

Since the rate of dissolution will be impacted by the turbulence level generated by the gas driven flow, larger ACD and lower gas generation rate (low current density) positively influence current efficiency. However, at a fixed dissolution rate of aluminum from the cathode, lowering aluminum production rate (lower current density) will reduce current efficiency. This is the coupling issue that will only be resolved by experimentation.

\section{Electrolyte Circulation}

The electrolyte flow in the cell is important to three of the cell performance criteria:

- current efficiency;

- operating near the alumina saturation concentration; and

- minimizing the influence of gas hold-up on the ohmic resistance in the ACD.

The current efficiency influence has been reviewed. The same models used to gain a better understanding of current efficiency for the proposed cell were also used to estimate the change in alumina concentration as a result of consumption by electrolysis. The analysis has shown that, for the flow fields predicted, the drop in alumina concentration in the bulk. electrolyte in the $\mathrm{ACD}$, even in regions of recirculation, are small, approximately $0.1 \%$ alumina. The target for the cell design is $0.50 \%$ drop in alumina concentration on passage through the ACD. This analysis assumed that dissolution rate was a fixed function of concentration difference at the alumina feed location in the cell.

Due to some of the limits of the numerical simulation of electrolyte flow, physical modeling was also used to assess cell design options relative to alumina concentration. It was also used to assess the influence of gas driven electrolyte flow and cell geometry on gas hold-up in the ACD. A physical model of the proposed cell design has shown that velocities in the ACD will range from 0.7 to $9 \mathrm{~cm} / \mathrm{sec}$. The velocity required to achieve $<0.1 \%$ drop in alumina concentration is $0.1 \mathrm{~cm} / \mathrm{sec}$. Details of the cell geometry, upcomer size, downcomer size and dam positions and sizes, have been established to minimize gas 
hold-up in the ACD. The expected relative resistivity ratio of the electrolyte, with and without gas hold-up, is 1.1 for operation at $0.25 \mathrm{~A} / \mathrm{cm}^{2}$ and 1.23 at $0.50 \mathrm{~A} / \mathrm{cm}^{2}$ for the vertically arranged cell design. The predicted cell voltage, 3.80 volts, includes this influence of gas hold-up.

\section{Thermal Design and Control}

The thermal design of the cell was used to establish the operating performance of the cell within a set operating temperature range and assess the method proposed for power control of the cell. The power control allows adjustment of the power generated to account for variability in construction techniques and changes in the quality of the cell insulation and operating characteristics over time. Without power adjustment, aluminum smelting cells would be inoperable. Alcoa cell design software that is used frequently by Alcoa for conventional smelting cell design, was used to establish the lining design and operating characteristics of the proposed cell. The predicted cell amperage and voltage are $131 \mathrm{kA}$ and 3.80 volts. The heat loss required to achieve an operating temperature of $950^{\circ} \mathrm{C}$ is 89 $\mathrm{kW}$. This is about $1 / 3$ of the heat loss for a conventional aluminum-smelting cell operating at this amperage. This is based on a current efficiency of $93 \%$.

The cell was designed to have a frozen ledge to protect the cell lining materials as in conventional cells today. But the thermal analysis shows that a $131 \mathrm{kA}$ cell of this design will be much more sensitive to changes that influence the thermal balance of the cell. The main result of this could be large changes in ledge thickness profile with small changes in voltage, heat loss as \% CE or load. For example, 0.05 volt change in cell voltage could change the ledge thickness one inch. This sensitivity could also render a high energy efficient cell inoperable. The power control in a conventional cell is done by movement of the anode bridge to adjust ACD. This cell design utilizes an interleaved electrode design to control current density rather than ACD, which provides a much finer tuning of cell voltage than control of ACD. The finer tuning offsets the higher sensitivity of an energy efficient cell and is predicted to provide the control necessary for operability.

\section{Cell Performance and Economics}

The cash cost saving for the cell design is based on the predicted energy savings for the cell room and carbon plant and labor reduction as a result of eliminating carbon changing. Since the design is very preliminary, capital estimates have not been included in the cost estimate. All materials required to reline cells and assemble electrode modules have been included in the operating cost. The material costs are based on material recycling and a 2000-day lining life and 1100 day anode life. The present anode life is estimated to be 220 days. This short anode life was recognized prior to initiating the project. This project is focused on verifying a cell design that can achieve cost savings that justify improvement of anode life and process commercialization. Once it is verified that the cell concept can provide the energy savings and productivity goals, anode material life will be addressed. 


\section{Cermet Anode Materials and Fabrication}

The goals of this task were to establish the raw material, processing steps and conditions for manufacturing cermet anodes of the following compositions: $\mathrm{NiO} / \mathrm{Fe}_{2} \mathrm{O}_{3}$ weight ratio of 1.07 at $17 \mathrm{wt} \%$ and $27 \mathrm{wt} \% \mathrm{Cu}$ with and without aluminum. The main process steps are synthesis of the nickel ferrite, blending the nickel ferrite with Cu powder, and isostatic pressing and sintering to form the cermet shape. Since many of the raw powders previously used for anode fabrication were no longer available, Alcoa had to characterize the $\mathrm{NiO}, \mathrm{Fe}_{2} \mathrm{O}_{3}$ and $\mathrm{Cu}$ powder and establish the appropriate processing conditions to produce the desired attributes of the ferrite product. The key attributes of the cermet power are no unreacted Hematite, a mean particle diameter of $31 \mu$, and good flowability and pressing characteristics. The primary measure of pressing characteristics is percent porosity after sintering. The goal for porosity is $<0.25 \%$. The raw powders and processing conditions have been established by Alcoa to meet the ferrite attributes required.

Only the Alcoa ferrite was used to establish the conditions for producing the cermet anodes of the compositions indicated. Anodes have been successfully produced for all compositions except the $27 \% \mathrm{Cu}$ composition without aluminum. These anode compositions can all be manufactured and achieve the microstructure and percent porosity required. The anodes that were produced with aluminum additions do not show the presence of aluminum, as a metal phase, in the X-ray images.

\section{Cermet Anode Properties and Anode Assembly Design and Anode Corrosion Tests}

The key electrical and mechanical properties are electrical conductivity, flexure strength, compressive strength and thermal expansion. These data were measured for the different anode compositions, then used for design of the electrode assembly. The electrical conductivity of the $27 \% \mathrm{Cu}-0.75 \% \mathrm{Al}$ is a factor of 10 higher $\left(\approx 1100 \mathrm{ohm}^{-1} \mathrm{~cm}^{-1}\right)$ than the $17 \% \mathrm{Cu}$ cermets. This is a factor of 5 higher than the carbon anode used in conventional cells. All the cell performance predictions are based on the more conservative $17 \% \mathrm{Cu}$ cermet anode properties.

The thermal mechanical data was used to complete a preliminary structural design of the anode at $950^{\circ} \mathrm{C}$. Stresses in the anode around the connection between the anode and the collector bar and stresses in the anode around its mechanical support were estimated. These stresses were found to be more than the thermal stresses in the regions which are removed from these two areas. It was shown that with proper design, stresses in the anode away from the collector bar areas, can be kept in the range of 0.5 to $1.0 \mathrm{ksi}$. The corresponding probability of failure is less than 5\% per plate based on the anode properties measured. The stress in the collector bar largely depends on the connection details. With proper choice of the connection details the stress can be as low as $3 \mathrm{ksi}$. The corresponding probability of failure is about $15 \%$. During Phase I, an apparatus was constructed to test, at temperature, the strength of anode collector bar connection. Connections will be tested before finalizing this part of the design and estimating the connection's probability of failure. 
Fifty hour electrochemical corrosion tests have shown the $27 \% \mathrm{Cu}-0.75 \% \mathrm{Al}$ cermet to perform similarly to the $17 \% \mathrm{Cu}$ cermet composition, but microscopic analyses indicated greater metal phase loss for the higher metal phase material.

The anode material selected for Phase II testing was the $17 \% \mathrm{Cu}$ cermet composition because of the large amount of data available on this material relative to the new candidates.

\section{Pilot Cell Design and Facility - Test Heaters and Electrolyte Containment}

The purpose of this task was to design the pilot cell facility and then test key elements of the cell to be used to assess the viability of the electrode assembly for commercial cells. Detailed layout drawings of the pilot cell facility were completed that define equipment locations and equipment details. The cell was designed to be capable of testing a full scale anode assembly at up to $5 \mathrm{kA}$. It was designed to be externally heated at this scale to separate the thermal design from the electrochemical engineering design of the electrode assembly. Therefore, two areas that required high design integrity were the heating system and electrolyte containment.

The heaters to be used for the pilot cell were tested for 30 days, under the conditions expected. They operated at $1010^{\circ} \mathrm{C}$ for this period at a very steady resistance and were physically in very good condition when removed form the test rig.

The main strategies to insure electrolyte containment in the pilot cell are to minimize electrolysis at the high density graphite containment crucible and to provide an electrically resistive sodium barrier. It is known from the literature that sodium deposition on graphite is the main cause of electrolyte containment degradation. As part of a bench scale anode corrosion test, a lining similar to that being considered for the pilot cell was used. The bench scale design was similar in that it was externally heated and used a graphite crucible for containment. The primary electrolyte containment was an alumina crucible. This bench scale cell contained electrolyte for 22 days and for part of that time the primary containment of the alumina crucible was breached. The alumina crucible dissolved during the 22-day period, exposing the graphite crucible to the electrolyte. No electrolyte was lost from the graphite crucible. Tests were continued in Phase II using the bench scale cell for . the dual purposes of anode corrosion and electrolyte containment testing.

\section{Phase I Conclusions and Go/No-Go Decision}

The key accomplishments during Phase I (Concept Development) were:

- interleaved electrode assembly design that can be retrofitted and achieves a $20 \%$ reduction in specific energy in the cell room;

- cell that incorporates a gas driven circulation system to maximize alumina dissolution and operability near alumina saturation concentration; 
- operation at low current density to minimize anode corrosion and improve operability near saturation concentration; interleaving electrode module that allows power control at high energy efficiency;

- improved anode compositions that results in $10 x$ higher electrical conductivity that enables productivity improvements in combination with energy improvements; and

- an estimated cost saving between 5-7 $\phi / \mathrm{b}$ not including capital differences.

The objectives of Phase I were achieved, and it was decided that the concept elements should be tested in Phase II.

\section{PHASE II OBJECTIVES}

The main purpose of Phase II was to demonstrate key elements of an overall cell design at a scale that minimizes cost, while providing sufficient size for confident scale-up to a 15-100 kA prototype cell. The Phase II pilot cell has been designed to operate in the 0.5-3 kA range. In this ampere range, an anode-cathode assembly between a half to full-scale of a commercial assembly can be tested. Multiple cell tests (one month in duration), will be conducted to debug and build confidence in the critical design elements that need to be proven before a prototype demonstration program is undertaken.

The cell design elements to be tested during Phase II include:

- cell performance, considering voltage and current efficiency, for the selected design features especially anode-cathode distance and anode composition;

- cell operability, considering length of continuous operation, sludge formation, alumina feeding, metal tapping, and material problems;

- electrode arrangement, considering electrolyte flow, alumina saturation, and aluminum collection;

- anode design, considering thermal stresses, collector bar connections, current distribution, and electrolyte flow; and

- anode and cathode durability and stability, considering breakage, cell start-up issues, and metal pad purity.

In addition to the elements of the cell design, the main elements for the commercial production of cermet anode will be established. The major milestones to be accomplished during this Phase include:

- cell operability - one month of operation with no major problems such as sludge

- formation, difficult metal tapping, electrolyte loss;

- cell performance - $>85 \%$ current efficiency and operation at a $2.5 \mathrm{~cm}$ (1 in.) anode-cathode distance;

- anode performance - breakage $(<10 \%)$ and metal pad purity $(<0.03 \% \mathrm{Ni}, 0.03 \% \mathrm{Fe}$ and $0.10 \% \mathrm{Cu}$ );

- alumina feed system - maintain alumina within $\pm 0.5 \mathrm{wt} \%$ alumina at saturation; and

- economic assessment of cell concept, materials and performance that gives a $20 \%$ ROI based on a retrofit implementation. 
Successful completion of these milestones will lead to prototype demonstration at $15-100 \mathrm{kA}$.

\section{PHASE II RESULTS}

\section{Pilot Cell Facility - Final Design and Construction}

\section{Bench Scale Simulation}

A Phase II bench scale simulation of the pilot cell was tested. Autopsy of this unit revealed that bath had penetrated the graphite crucible and briefly contacted the outer Inconel shell after four weeks of operation. Air burning of the graphite was significant near the top of the crucible; and this problem added carbon to the bath late in the test. An improved gas seal system was then tested in a follow up simulation, which prevented air burning of the graphite crucible.

\section{Final Cell Design Features}

The large graphite crucible for the pilot cell was re-impregnated to reduce its porosity and bath penetration compared to the bench scale simulations. Monofrax $M$ alumina bricks were used to isolate the large graphite container from the anode assembly in this cell. Each heater had an argon purge and a rope seal from the heater to the top of the heater hole to help protect the hottest part of the graphite from air burning.

The final pilot cell design used $\mathrm{TiB}_{2}-\mathrm{G}$ plates as the vertical cathodes and as bottom and sidewall bath barriers. The sole vendor SGL Carbon group provided these.

The design of the anode module was set at 3 anode plates; and the anode plate was sized at $14.5^{\prime \prime} \times 1.0 " \times 6.0 "$. The first cell was designed to test two modules and operate at a total of 500 to 1000 amps.

The anode collector bars were nickel pipes, which were sized to minimize the net heat loss from the anode connector through the insulated lid. The heat generated from the voltage drop in this connector nearly matched the heat loss out the connector in order to avoid thermal stresses in the cermet anode and freezing of the bath in the anode module.

Cathode connector rods for the pilot cell were vertical and entered the aluminum metal pad from above. One-inch diameter tungsten rods served as cathode connector rods for the first pilot cell. The surrounding graphite crucible can also be made cathodic, but this could enhance bath penetration.

The cathode plates and Monofrax sidewalls were installed in the energy efficient cell prior to the anode modules. The cathode plates were aligned to achieve reasonably consistent anode to cathode spacing before final insulation of the two anode modules. 
A full scale Plexiglas model of the electrode assembly had been built to facilitate correct fabrication of the electrode assemblies. The anode assemblies were assembled and lowered into the cell. The anode-cathode distances for the different gaps were measured. Only one cathode plate was not in a near perfect vertical position. Monofrax blocks were placed below the anodes to support an anode if an anode cracked and dropped. Aluminum lids were installed on top of the cathodes to help pre-wet them

The bath melter was designed such that bath could be melted in this unit and then pressure tapped from this unit into the pre-heated pilot cell. Analyses of stresses under thermal shock situations such as cell startup show no mechanical failure provided the anode module does not become locked in crust followed by a thermal transient. The cell was heated from the side and bottom (because it was in a graphite crucible), and it had an insulated lid to avoid crust formation.

\section{Phase II Anode Fabrication Method}

A controlled atmosphere design was incorporated into an existing furnace for sintering pilot scale anodes. An oxygen analyzer was calibrated for use during controlled atmosphere sintering of the anodes.

Data was generated to design the molds for making anodes for the pilot scale test. These were designed to produce fabricated anodes of sizes $141 / 2$ in $\times 6$ in $\times 1$ in. The powder pressed well in the large bag mold and in-house fabrication of anodes of the desired geometry was demonstrated. The density, porosity and microstructure of larger anodes compared favorably with properties determined for smaller anodes.

Molds for producing other anode assembly components (using the cermet type material) were also designed and the production of large parts was demonstrated.

\section{Anode-To-Collector Bar Connection Method}

Initially pilot scale anodes were produced with a graded composition of metal-cermet ending with completely metallic area at one end for collector bar connections.

Samples were designed and prepared for measuring the anode to collector bar joint strength. Anodes with various lengths of graded connection areas were fabricated to assure that parts could be fully sintered with a larger graded zone. The Cermet to bus bar joint strength as well as weld integrity was studied. It was determined that the graded composition should end with completely metallic area in order to obtain a good weld. If the weld area contains oxides, porosity develops in the weld area.

Early anode plates developed tiny cracks below the graded composition. It appears that the crack was formed during cool down after sintering. The differential thermal expansion and heat capacity of the metallic and cermet areas contributed to stress. Test results indicate that binder additions in the metallic area can be used to reduce shrinkage mismatch between the metallic and cermet areas during sintering. It was also found that addition of isostearic acid mold lubricant improves green strength. Other experiments included reductions in cool down rate and use of less sharp grading, but these did not significantly reduce the 
cracking problem. It was also found that the pressure release rate with the existing press and current setting was too severe and leads to cracking at the metal cermet area for large pieces. The pressure release rate for the existing press was minimized, but the problem was not completely solved.

Because the aforementioned cracking problems could not be resolved rapidly, another method for joining cermet anode with metal conductors was also evaluated. It is possible to reduce a small portion of the cermet by submerging that part of the anode in charcoal and reducing that part of the anode at about $1000^{\circ} \mathrm{C}$. This forms a reduced area on the cermet that is suitable for joining a metal conductor. The samples produced using this technique contained no visible porosity or imperfection either at the reduced area or at the boundary of reduced area and the cermet. The reduction is limited in size and area provided the anode part, which is not exposed to charcoal, is maintained in a controlled oxygen environment. Reduction of anode areas not necessary for joining should be avoided. This technique worked well with the standard Cermet material. It was demonstrated that approximately 2 inches of one end of full size Cermet anodes could be reduced. The reduced end must be machined flat prior to diffusion welding.

A diffusion welding apparatus was setup to join the reduced end of the large cermet anodes with a Ni 200 bar. The diffusion welding was carried out at $900-1000^{\circ} \mathrm{C}$ with a load of approximately 5-psi. Diffusion welding was much less disruptive than conventional welding. Conventional welding techniques were employed to join the other end of the $\mathrm{Ni}$ bar to an Inconel collector bar. These techniques were found to be suitable for joining cermet anodes with metal conductors. The reduced cermet and $\mathrm{Ni}$ metal have very low strength at $900-1000^{\circ} \mathrm{C}$, and the design of the anode assembly takes this into consideration.

\section{Fabrication of Pilot Anodes and Anode-To-Collector Bar Connections}

All pilot scale anodes were reduced and diffusion welded to Ni 200 bars. Two assemblies (or modules) each containing three anodes were prepared by conventional welding of Inconel plates to the $\mathrm{Ni} 200$ bars. There were tiny surface cracks on the reduced cermet area next to $\mathrm{Ni} 200$ of some anodes. One anode was used which had small cracks in noncritical areas of the cermet region. All anode and structural materials made of cermet composition were successfully fabricated and sintered.

\section{First Pilot Cell Operations}

Heat up of the pilot cell to operating temperature took 9 days with power provided by low voltage heaters inside the wall of the graphite crucible. The heat transfer design provided most heat through the bottom and lower sidewalls of the pilot cell. After the cell reached operating temperature, approximately $400 \mathrm{lb}$ of molten electrolyte was transferred to the cell from the bath melter. The bath was pressure tapped through an insulated tool steel pipe, which was resistance heated by one of the rectifiers.

The pivotal event for the first pilot cell was persistent low voltage at startup of electrolysis caused by aluminum in the electrode compartments and on several anodes. Volt-amp 
curves gave extrapolated voltages less than 2.2 which is the minimum required to produce aluminum and oxygen. These results indicated that the compartments were at least partially shorted from anode to cathode; or alternatively, the cell may be operating as a transference cell because of aluminum on the anodes. This could have been caused by aluminum plates falling against the anode or bath transfer causing metal to splash on the anode. Prior to heating of the cell, aluminum plates had been placed leaning on the cathodes in an attempt to pre-wet the cathode plates before bath was introduced. The east module carried higher current than the west module indicating greater shorting, the east module compartments could not be cleared effectively. The east module had more tolerance problems than the west module resulting in closer anode to cathode distances.

Lancing of electrode plates and compartments with argon was effective at eliminating shorting and metal on the anodes for the West module for several hours. Because of these procedures, the west module did operate for several hours at the correct extrapolated voltage for producing oxygen and aluminum, 2.2 to 2.3 volts, as shown in Figure 4 . The overall cell resistance was low, $0.0029 \mathrm{ohms}$, based on the slope of the volt amp curve versus a calculated value of $0.0051 \mathrm{ohms}$. This lower resistance was probably due to some metal in the compartments reducing the anode to cathode spacing. There was no indication of high voltage problems anywhere, and this implies all critical interfaces were low in resistance including: gas film, cathode connector to the aluminum metal, the reduced region of the cermet anode, and Inconel and nickel welds. The total cell voltage drop was low: 3.0 volts at 250 amps for the west module (after being cleared of shorts) versus a design of 3.3 to 4.0 volts at 250 amps. Even at twice the design current density, the voltage drop was at 3.7 volts at 500 amps.

During a very brief operating period, current efficiency was estimated to be over $78 \%$ by alumina depletion. This result is not adequate to prove acceptable current efficiency in a stable electrode cell -only an indication it may eventually be possible.

No frozen crust was formed on top of the bath early in this run, and this indicates that heat losses from the lid and vertical electrode connections (both anode and cathode) were minimal as required to achieve the desired energy reductions for a commercial cell. Unfortunately, a sludge layer formed at the bottom of the cell near startup and prevented removal of metal. Oxide analyses indicated that the bath was higher than saturation in alumina at startup $-11.5 \%$ versus about $7.2 \%$ saturation. It is believed that these high values are because the bath contained higher than normal silica. The cell had large amounts of sludge at the end of the run. Mechanical damage and fume attack caused significant insulation containing silica to fall into the bath. Also feeding alumina while not producing aluminum during most of the operation also added sludge to the cell. Oxidation of $\mathrm{TiB}_{2}$ may have also contributed to the sludge

During operation sodium losses were minimal and small amounts of $\mathrm{AIF}_{3}$ were added instead of $\mathrm{NaF}$ which is just the opposite of a typical Hall cell. Thus bath penetration of the crucible and evaporation of the bath components were minimal.

The cell was shutdown because the west module could not be maintained un-shorted without continuous attention and because of sludge problems. 


\section{First Cell Autopsy}

Autopsy revealed that the cell was loaded with sludge, which was found to be electrically conductive. Cathode plates were not wet by aluminum. This could have prevented proper drainage and contributed to the formation of short circuit metal paths. During heat up of the cell, steam was released from the cell lining at higher temperatures than expected and this could have oxidized $\mathrm{TiB}_{2}$. Silicon deposits were present because of high silica in the bath. Aluminum was missing from the cell. Silica from bath and insulation, titania and boria from oxidized $\mathrm{TiB}_{2}$ could all have reacted with aluminum to form conductive sludge and cause the disappearance of aluminum.

Nickel anode connectors corroded severely in the weld region while key Inconel components held up much better than the nickel weld areas. Autopsy identified short circuits between cathode and lid. Current measurements made near startup showed correct current balances between anode modules and cathodes. Autopsy revealed that anode modules, cathode plates, and sidewalls had maintained structural and dimensional integrity during startup and operation, which included severe shorting and sludge formation problems. The west module operated periodically at 2.5 time's nominal current density without known thermal shock failure of the anodes. The autopsy also revealed that sodium penetration of the graphite was minimal and the heater holes had not been penetrated by bath. The graphite crucible and heaters were in good condition and could be used for the next run.

\section{Bench Cell Tests Following First Cell Autopsy}

A large bench scale cell was designed and several tests were done in order to understand the autopsy results and the operational problems. For most tests, the cell had one inert anode and two vertical cathode plates as shown in Figure 5 and it operated at about 40 amperes. These tests gave some surprisingly low values of current efficiency, which yaried from $25 \%$ to $66 \%$. It is believed that the very poor results ( $25 \%$ to $40 \%$ ) were due to poor aluminum drainage from the vertical cathodes. This poor drainage was probably due to non-wetting of the $\mathrm{TiB}_{2}-\mathrm{G}$ due to inconsistencies of the $\mathrm{TiB}_{2}-\mathrm{G}$ plates. Some of the tests, which simulated various aspects of the pilot cell, produced non-conductive sludge: but most were not shorted and none produced conductive sludge. It is believed that the conductive sludge in the first pilot cell was probably due to continued operation of the cell with aluminum on the anodes and / or aluminum short circuit paths between anodes and cathode after low voltage characteristics were observed at startup.

\section{Design and Construction of Optimized Cell}

The pilot cell was redesigned in order to eliminate or at least reduce the problems experienced in the first cell test. The bottom structure supporting the cathodes and including metal sumps and a center located sludge sump was changed to a monolithic piece of graphite instead of large $\mathrm{TiB}_{2}-\mathrm{G}$ plates. Cathodes were increased form 0.5 inch to 1 inch thick and anodes were increased from 1.0 inch to 1.25 inch to guarantee structural integrity 
if de-sludging operations were required during the optimized run. The anode to cathode spacing was increased from 1.0 inch to 1.5 inch and aluminum plates were not used to prewet the cathodes in order to reduce the possibility of short circuits and aluminum on the anodes. These changes reduced space and the anodes per module from three to two. The top of the cathode plates were rounded and fit with boron nitride caps in order to prevent metal from being produced on top of the cathodes. The flat top and sharp edges of the cathodes used in first cell test were considered a problem for metal drainage. Anode module structures, which provided circulation, were eliminated. This allowed the overall anode height to be reduced and also improved access to the electrode compartments. The lid was changed to encapsulate the silica bearing insulation with Inconel while the lid material facing the bath was still made of high purity alumina board.

The rectifiers for the DC heaters were connected in series such that a higher voltage could be achieved. This increased the power capability of the heaters, and the total power available for the cell was increased from 36 to $48 \mathrm{~kW}$ to allow reasonably rapid bath melting within the cell. The start up procedure was then changed to melt the bath within the cell rather than in a separate bath melter

The nickel anode connector and weld region was replaced with a larger Inconel pipe in order to increase the high temperature strength and to avoid corrosion problems.

Remaining nickel components were enlarged to greatly reduce the stress and thus allow up and down movement of the anode modules within the cell. The anodes could be held above the bath but still inside the cell (beneath the lid) while the bath was melted. The anodes could then be lowered into the bath after it was melted within the cell. This new procedure allowed slow heat up of the anodes while reducing the possibility of aluminum on the anodes at startup.

The synthetic bath used in the first cell test had a questionable silica content and was replaced with Hall cell bath from Alcoa's Warrick smelter.

\section{The Optimized Cell Test}

The cell was heated for two days to remove water before it was charged with $400 \mathrm{lb}$ of bath. Heat up continued for four days followed by bath melting which took about 5 hours. After operating temperatures were reached, both anode modules were lowered into the bath and DC electrolysis was initiated. The modules were connected in parallel to separate DC rectifiers such that they could be controlled independently. Initially the extrapolated voltages were low $(1.25 \mathrm{~V})$ but recovered in about one hour such that reasonable extrapolated voltages of about 2.25 volts were obtained indicating production of aluminum and oxygen in both modules. After 12 hours of operation, volt amp curves shown in Figure 6 show extrapolated voltages of 2.3 and nearly identical resistance for both modules. There was no increase in total voltage from startup. Metal level measurements showed that significant metal had been produced and drained to both sumps. Aluminum was successfully removed from the cell by ladling from both sumps. 


\section{Current Efficiency Experiments}

After several days of operation, experiments were done to improve current efficiency. These included raising anodes such that the interleaved region between anode and cathode (also referred to as the shadow area) was reduced to decrease the amount of oxygen rising from the anode, which could contact the aluminum on the cathode plates. The higher the anode is raised relative to the cathode, the lower the possibility that a rising and expanding vertical plume of oxygen can contact the nearby cathode surface and react with the aluminum to reduce current efficiency. The other type of experiment was to increase the current density, which is expected to increase the production of aluminum without increasing the back reaction of aluminum with oxygen. The amount of oxygen in the off gas was used to determine changes in current efficiency for these tests.

Raising the anodes to near zero shadow areas between anode and cathode did not produce a proven current efficiency gain indicating that the oxygen plume was not contacting the cathode or not causing an increase in the back reaction.

While raising the anodes gave no current efficiency gain, these tests did provide data on the change in cell voltage as a function of the interleaved area. The current density in the interleaved or 'shadow 'area is actually changing as the anodes are moved up or down relative to the stationary cathodes. These tests demonstrated a critical control algorithm for a stable electrode cell. A large movement in the anode produced a relatively small change in voltage and heat produced. This low sensitivity is required because the vertical stable electrode cell produces so much less heat than a conventional Hall cell. Control is possible because significant anode module movements will produce relatively small heat effects. Figure 7 summarizes these results.

Increasing current density from 0.3 to over $0.6 \mathrm{amp} / \mathrm{cm}^{2}$ did produce large nonproportional increases in oxygen from the cell. For example, a current per module of 150 amps gave $0.28 \%$ oxygen in the cell off gas while 225 amps per module gave an off gas as high as $1.3 \%$ oxygen- with the same high argon purge rate. Some of these results indicated current efficiencies over $80 \%$ while others were too high (over 100\%) indicating possible dilution of the off gas with ambient air. Unfortunately, anode module voltages were increasing at these higher current densities indicating severe anode wear via electrochemical corrosion. The last change to 300 amps caused catastrophic voltage increases to over 10 volts.

\section{Autopsy Optimized Cell}

The anodes were found to be severely worn in the active electrolysis region (down to under a $1 / 4$ inch) but not broken at least when first removed.

A plot of cermet anode constituents (iron, nickel, and copper) is shown versus time in Figure 8. A plot of nickel versus copper (Figure 9) indicates they are correlated and from the same source - the cermet anodes. These high total concentrations -over 30\% at the end of the test - would be expected to effect viscosity and wetting characteristics of the 
cathodes. The cathodes had no loss of any dimension or obvious structural damage and were relatively free of sludge. Closer examination indicated a wetted metal layer on the surface with separate striations of other materials on top. This indicates that there may have been cyclic periods of wetting and non-wetting of the $\mathrm{TiB}_{2}-\mathrm{G}$ cathode plates. There have been many instances of non-wetting with $\mathrm{TiB}_{2}-\mathrm{G}$ plates. It is believed that this causes a loss of current efficiency because of poor drainage and the formation of small droplets.

All the corners of the boron nitride caps on top of the cathode plates were gone but the centerpieces were intact and the bottom sidewall pieces of boron nitride had also not suffered significant dimensional losses.

The Monofrax plates did very well except at the bottom three inches, which was corroded with a black coloration. Some Monofrax was missing in direct contact with the graphite, and some holes, which almost appeared to be drilled, were found in the Monofrax near this region.

\section{Phase II Assessment}

For the first cell test, one module was cleared of a short circuit and did operate for several hours at the correct extrapolated voltage for producing oxygen and aluminum.

The optimized cell operated almost 20 days without significant short circuits in the anodecathode compartment or metal on the anodes -obviously a significant gain in performance.

The optimized cell operations were not significantly impeded by sludge formation for sustained periods of time, and some de-sludging procedures were successfully tested. No conductive sludge was formed. There was no breakage or known thermal shock failure of any electrode during either pilot test.

For several hours of the first cell test, the energy objectives of the project were achieved after one module was cleared of a short circuit. The voltages obtained in the optimized cell test also met the energy objectives of the project for at least two weeks - even though the anode to cathode spacing was increased from 1.0 inch to 1.5 inch compared to the first cell test. Reducing non-essential anode height in the optimized cell helped offset the greater anode to cathode spacing because the resistance of the anode was a significant component of the overall resistance of the cell.

Some of the high anode wear observed in the optimized cell test could have occurred near the end of the test based on large increases in cell voltage during high current density experiments. It is also suspected but unproven that the concentration of alumina during the test was significantly below saturation because of the presence of an unidentified oxygen bearing species.

At times there seemed to be good metal production during the optimized cell test based on gains in metal height in both sumps and alumina depletion, and metal was successfully 
tapped from the sumps. Near the end of the run, oxygen analyses of the off gas showed significant gains in current efficiency when the current density was increased.

Data was obtained on the effect of anode movement on cell voltage; and the ability to control a very low, heat loss cell with inert anode movement appears to be feasible.

An acceptable current efficiency was never proven during the pilot scale or bench scale tests with the vertical plate configuration. This must be done before a vertical cell concept can be considered viable. Anode corrosion rate must be reduced by at least a factor of three in order to produce commercial purity aluminum. It is recommended that extensive theoretical and bench scale investigations be done to improve anode materials and to demonstrate acceptable current efficiency results in a vertical concept cell before pilot scale work is continued. 


\section{FIGURE 4 VOLT - AMP CURVE FIRST CELL TEST WEST MODULE}

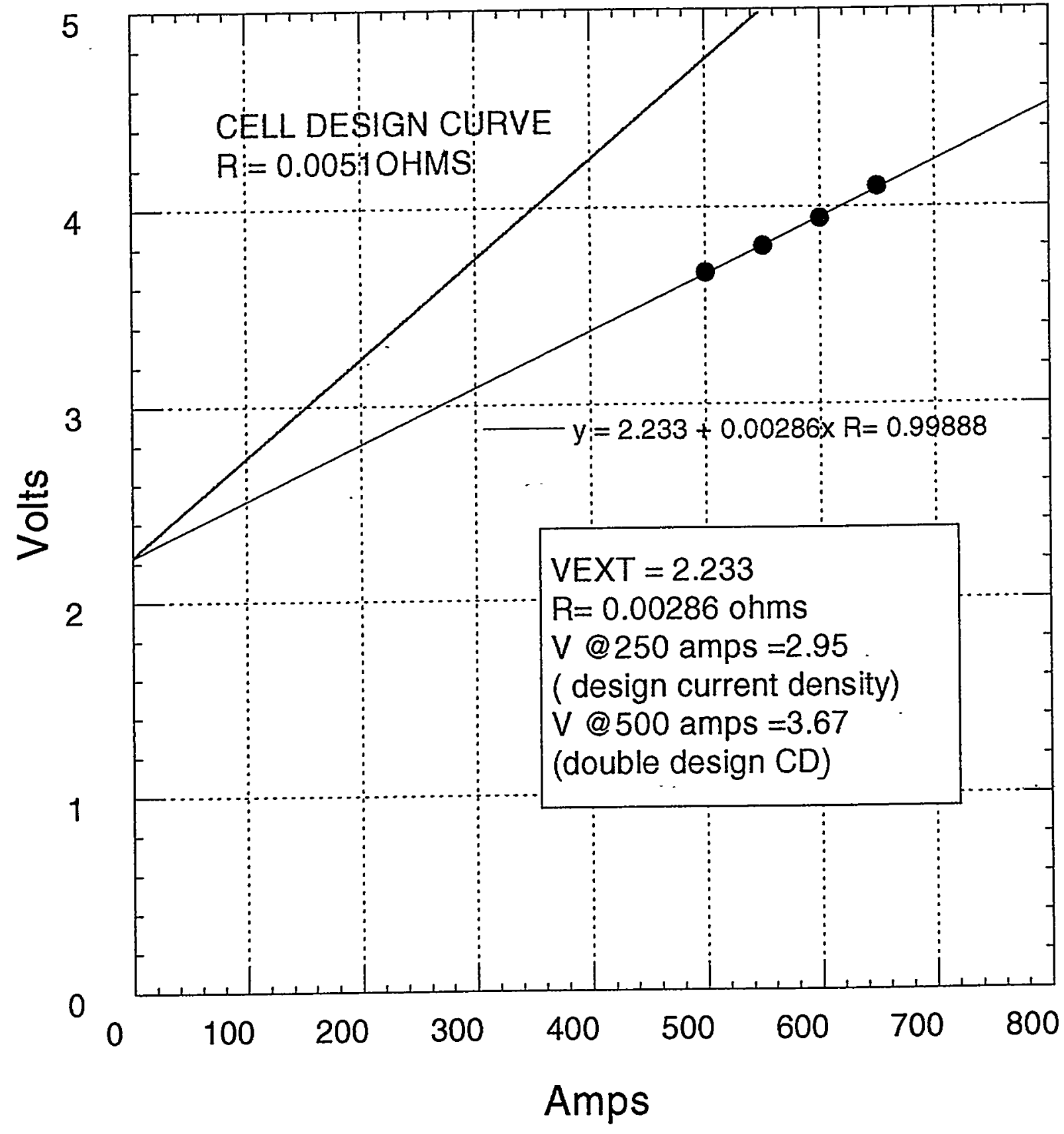


FIGURE 5

VERTICAL PLATE BENCH CELL

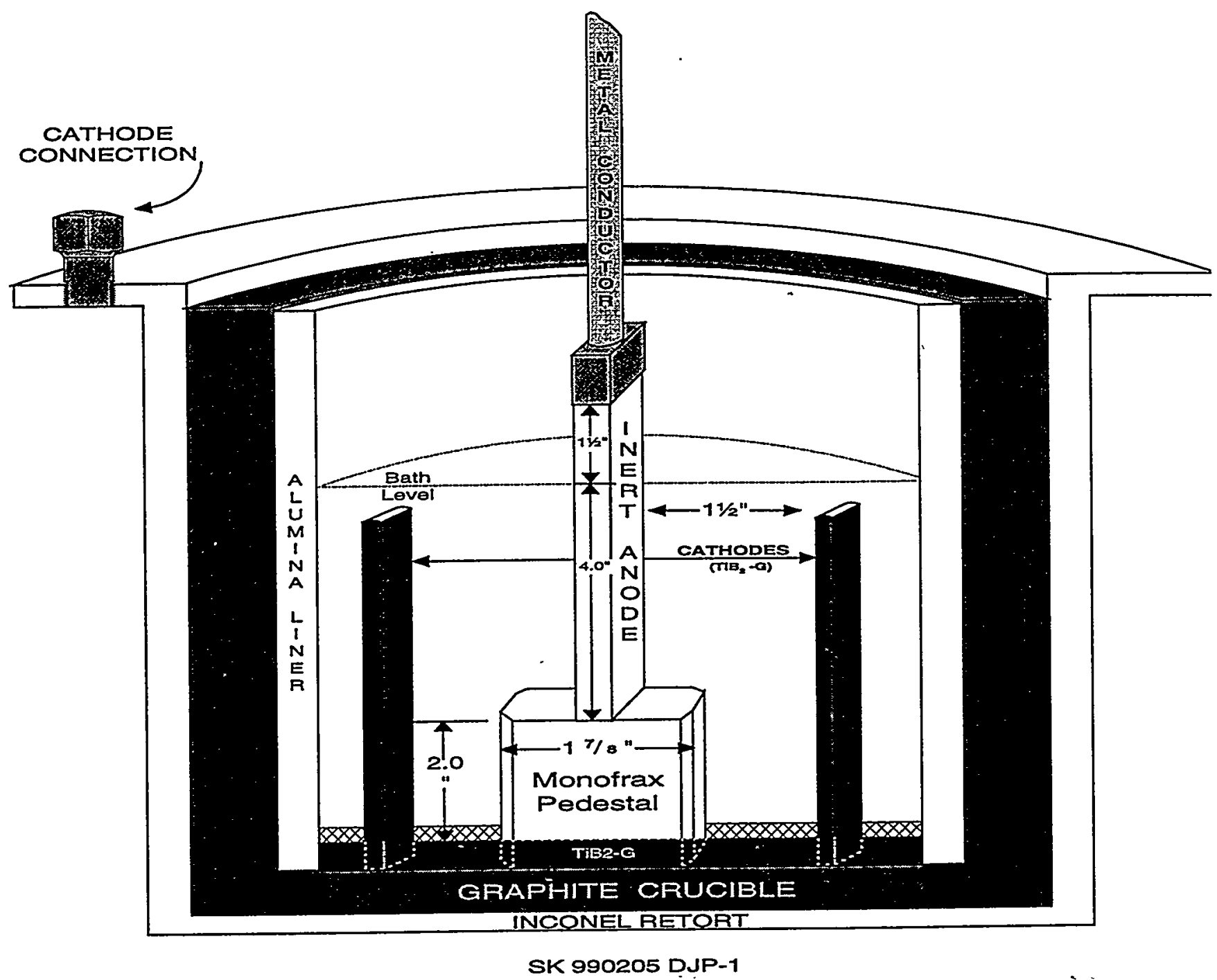




\section{FIGURE 6 OPTIMIZED CELL TEST VOLT-AMP CURVES}

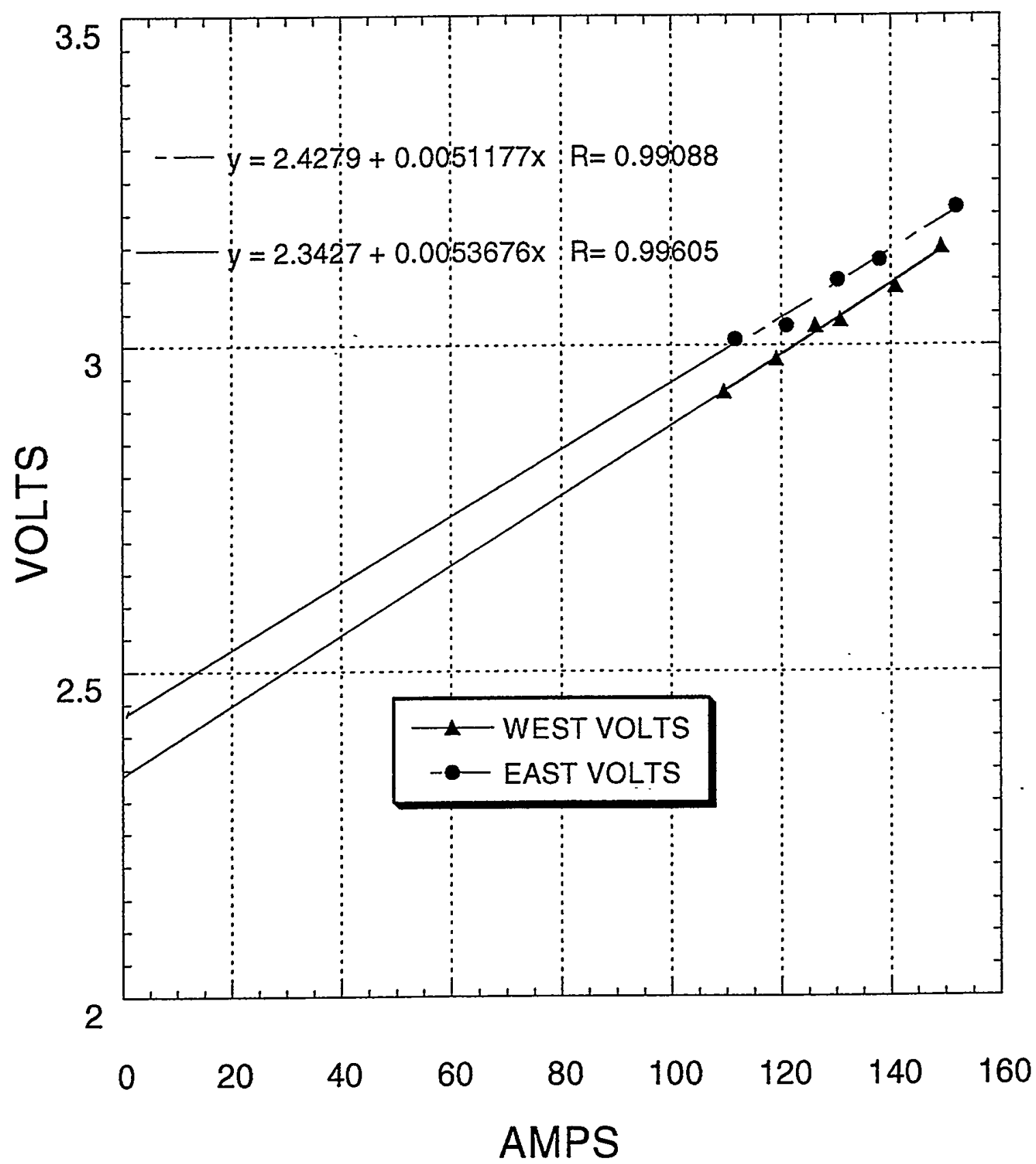


Figure 7

Influence of Anode Move on Cell Voltage

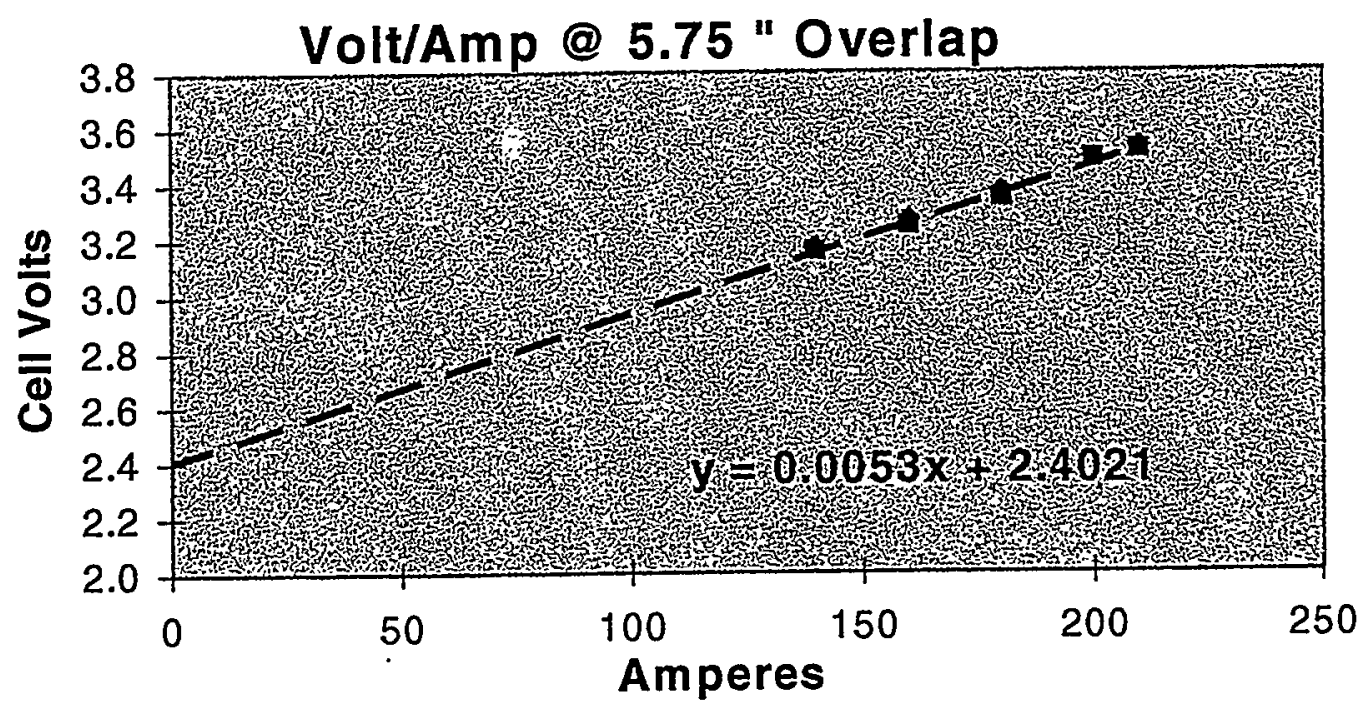

Volt/Amp@ @" Overlap

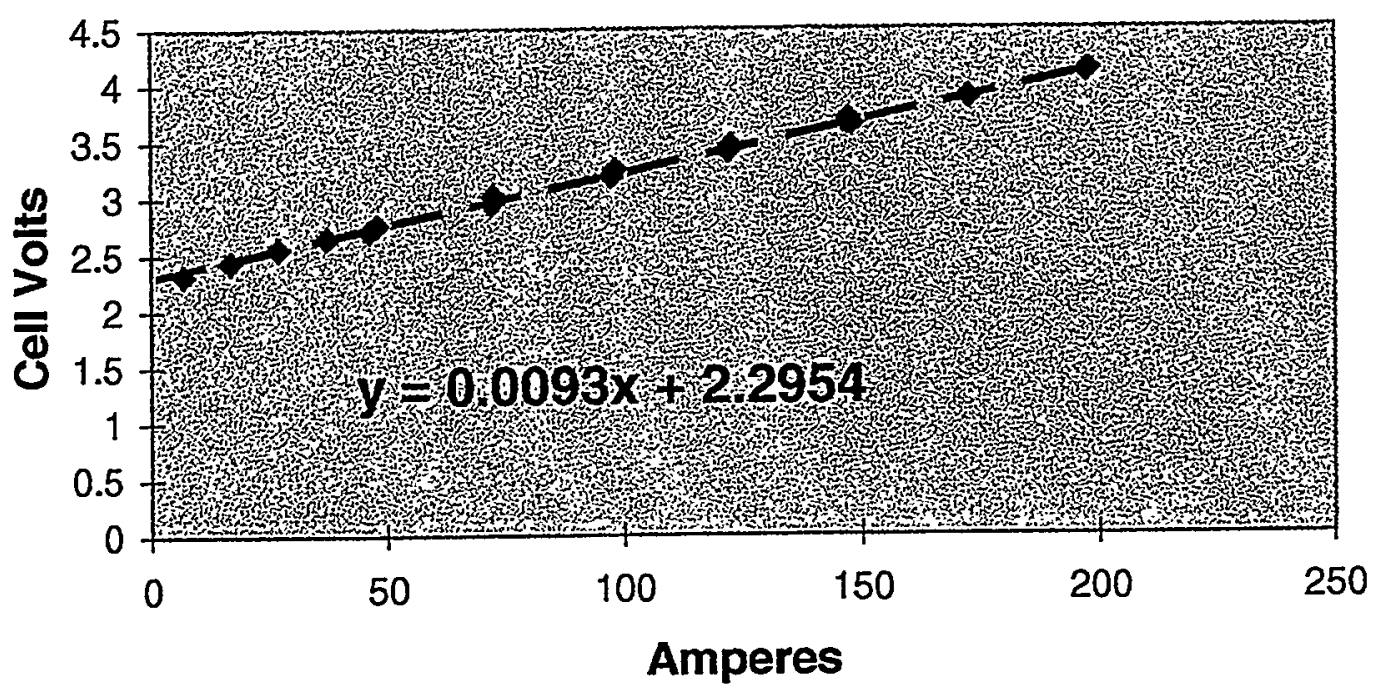

0.70 Volt Change for a 2.75' Anode Move 


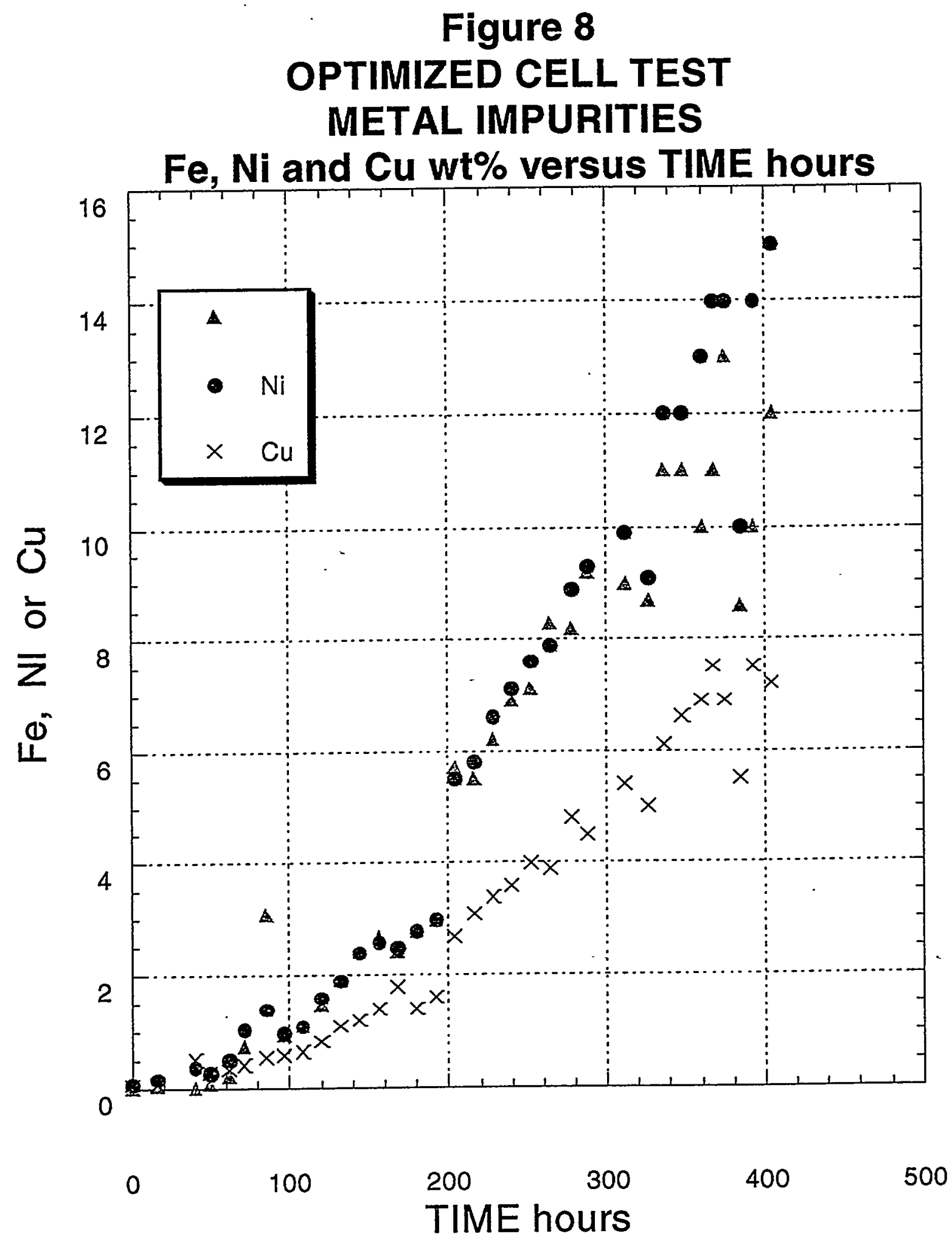


Figure 9 OPTIMIZED CELL TEST METAL
Ni VERSUS Cu

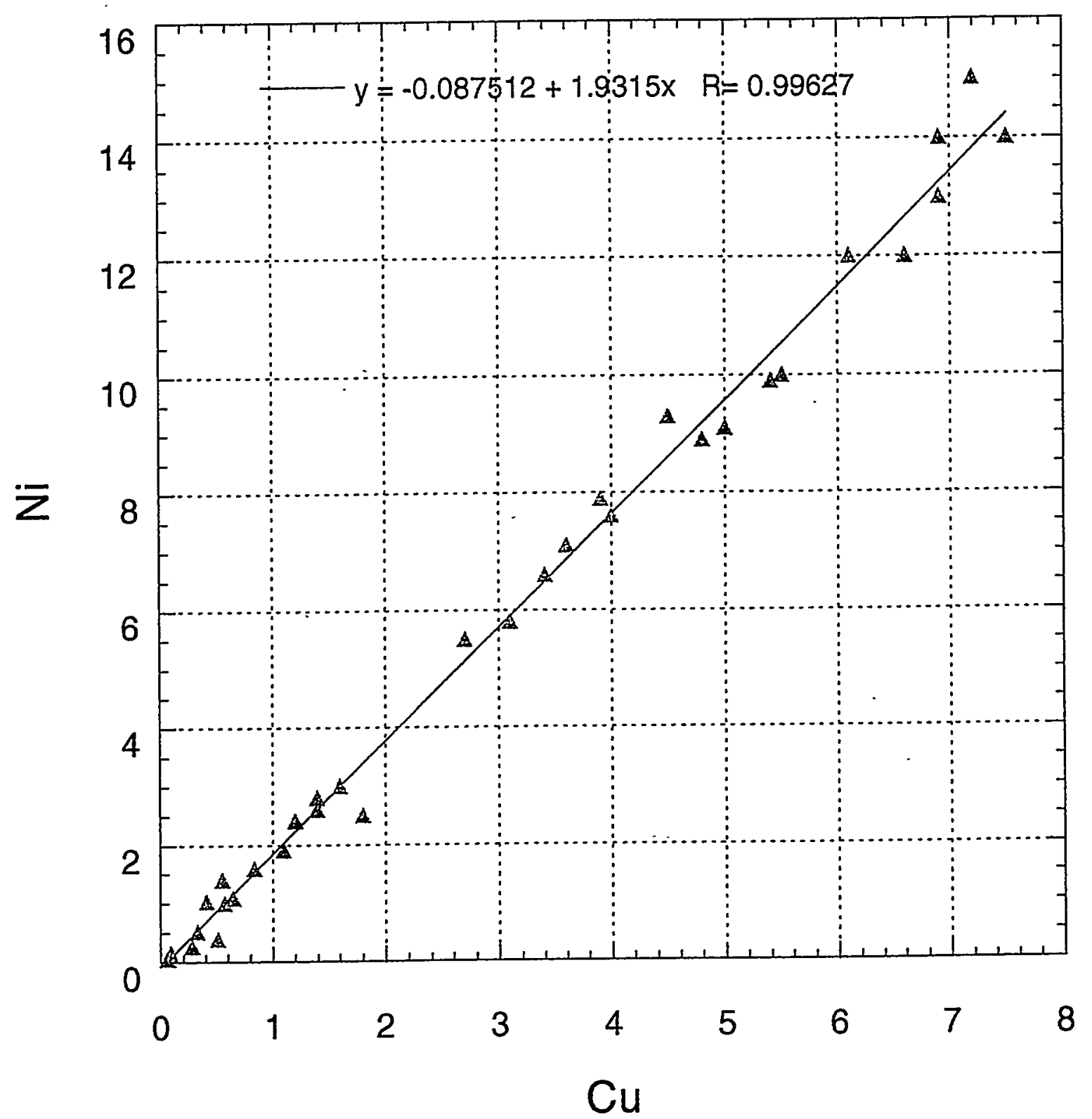

